\title{
Evaluation of oxygen isotopes and trace elements in planktonic foraminifera from the Mediterranean Sea as recorders of seawater oxygen isotopes and salinity
}

\author{
Linda K. Dämmer ${ }^{1}$, Lennart de Nooijer ${ }^{1}$, Erik van Sebille ${ }^{2}$, Jan G. Haak ${ }^{1}$, and Gert-Jan Reichart ${ }^{1,3}$ \\ ${ }^{1}$ Department of Ocean Systems, NIOZ Royal Netherlands Institute for Sea Research, and \\ Utrecht University, Texel, the Netherlands \\ ${ }^{2}$ Department of Physics, Institute for Marine and Atmospheric research Utrecht (IMAU), \\ Utrecht University, Utrecht, the Netherlands \\ ${ }^{3}$ Department of Earth Sciences, Faculty of Geosciences, Utrecht University, Utrecht, the Netherlands
}

Correspondence: Linda K. Dämmer (linda.daemmer@nioz.nl)

Received: 17 February 2020 - Discussion started: 10 March 2020

Revised: 11 September 2020 - Accepted: 17 September 2020 - Published: 30 November 2020

\begin{abstract}
The Mediterranean Sea is characterized by a relatively strong west to east salinity gradient, which makes it an area suitable for testing the effect of salinity on foraminiferal shell geochemistry. We collected living specimens of the planktonic foraminifer Globigerinoides ruber albus to analyse the relation between element / Ca ratios, stable oxygen isotopes of their shells, and surface seawater salinity, isotopic composition and temperature. The oxygen isotopes of sea surface water also correlate with salinity in the Mediterranean during winter, which is when sampling for this study took place. Seawater oxygen and hydrogen isotopes are positively correlated in both the eastern and western Mediterranean Sea, although the relationship differs from previously reported values, especially in the eastern region. The slope between salinity and seawater oxygen isotopes is lower than previously published results. Still, despite the rather modest slope, seawater and foraminiferal carbonate oxygen isotopes are correlated in our dataset, albeit with large residuals and high residual variability. This scatter could be due to either biological variability in vital effects or environmental variability. Numerical models backtracking particles show that ocean-current-driven mixing of particles of different origins might dampen sensitivity and could result in an offset caused by horizontal transport. Results show that $\mathrm{Na} / \mathrm{Ca}$ is positively correlated with salinity and independent of temperature. As expected, foraminiferal $\mathrm{Mg} / \mathrm{Ca}$ increases with temperature, which is in line with earlier calibrations, and in the
\end{abstract}

high salinity environment. By using living foraminifera during winter, the previously established $\mathrm{Mg} / \mathrm{Ca}$-temperature calibration is extended to temperatures below $18^{\circ} \mathrm{C}$, which is a fundamental prerequisite of using single foraminifera for reconstructing past seasonality.

\section{Introduction}

Ocean circulation plays an important role in the Earth's climate, as it redistributes heat and also impacts global biogeochemical cycles. Seawater temperature and salinity are key parameters for reconstructing ocean circulation, as together they determine seawater density and, in turn, large-scale circulation patterns, including a substantial part of the meridional overturning circulation. Reconstruction of past ocean environments largely relies on so-called proxy calibrations in which a variable that can be measured in the geological record is related to a target environmental parameter. The incorporation of trace metals in foraminiferal shell carbonate, for example, is a popular tool used to reconstruct past ocean parameters. More specifically, the incorporation of $\mathrm{Mg}$ (often expressed as the calcite's $\mathrm{Mg} / \mathrm{Ca}$ ) increases exponentially with seawater temperature, as first observed in culture studies (Nürnberg et al., 1996) and later confirmed by field calibrations (Anand et al., 2003).

In addition to temperature, salinity and inorganic carbon chemistry also affect $\mathrm{Mg} / \mathrm{Ca}$ in some species of 
foraminifera (Allison et al., 2011; Dueñas-Bohórquez et al., 2011; Geerken et al., 2018; Gray et al., 2018; Hönisch et al., 2013; Kisakürek et al., 2008; Lea et al., 1999). For the best possible accuracy, such effects need to be corrected for when using foraminiferal $\mathrm{Mg} / \mathrm{Ca}$ for the reconstruction of temperature; this calls for independent proxies for these other environmental parameters.

Currently, salinity is often reconstructed through indirect relationships with other variables, such as the ratio of stable oxygen isotopes of seawater, which are recorded in planktonic foraminifera (Rohling, 2007), although direct approaches have also recently been suggested (Wit et al., 2013; Bertlich et al., 2018). As the seawater oxygen isotope ratio and salinity are both affected by evaporation and precipitation, the two often are linearly related (Rohling, 2007; Bahr et al., 2013), with their calibration depending on local conditions. If foraminifera precipitate their calcite in equilibrium with respect to seawater oxygen isotopes, their $\delta^{18} \mathrm{O}$ should reflect that of the seawater and, hence, salinity. However, as the seawater temperature affects stable oxygen isotope fractionation during calcification (McCrea, 1950; Urey et al., 1951), independent temperature reconstructions are needed to estimate seawater $\delta^{18} \mathrm{O}$ from $\delta^{18} \mathrm{O}_{\text {calcite }}$ (Rohling, 2007). Independent temperature reconstructions can be based on organic proxies such as $U_{37}^{K^{\prime}}$ (Prahl and Wakeham, 1987), TEX86 (Schouten et al., 2006) or the $\mathrm{Mg} / \mathrm{Ca}$ of the foraminifera themselves (Mashiotta et al., 1999; Elderfield and Ganssen, 2000). The accuracy and precision of such reconstructions is debated, because the propagation of errors from the combined inaccuracies of the analyses and the uncertainties in calibrations due to combining several proxies is difficult to assess and seems too large for meaningful reconstructions of changes in salinity over time (Rohling, 2007). Due to the lack of a suitable alternative approach, the use of $\mathrm{Mg} / \mathrm{Ca}$ to determine the temperature effect of foraminiferal $\delta^{18} \mathrm{O}$ continues to be applied in settings that are prone to large changes in salinity, such as the Mediterranean Sea. This calls for an independent in situ calibration in which all of the parameters involved are measured and are not determined by proxy relationships.

Culture experiments using the benthic, symbiont-barren Ammonia tepida (Wit et al., 2013) and the planktonic Globigerinoides ruber (pink) (Allen et al., 2016) have shown that $\mathrm{Na}$ incorporation in foraminiferal shell carbonate is positively correlated with seawater salinity. A field calibration confirmed this positive correlation for the planktonic foraminiferal species G. ruber albus (Mezger et al., 2016), as well as for Trilobatus sacculifer (previously called Globigerinoides sacculifer) in the Red Sea and the Atlantic Ocean (Mezger et al., 2016; Bertlich et al., 2018). Comparison of $\mathrm{Na} / \mathrm{Ca}$-salinity calibrations shows, however, that absolute $\mathrm{Na} / \mathrm{Ca}$ values and sensitivities to salinity vary between species (Mezger et al., 2016).

When using field calibrations to constrain the accuracy and precision of potential reconstruction approaches, it is impor- tant to also consider the potential impact of lateral transport of foraminifera due to (ocean) currents. Foraminifera collected at a specific sampling location might actually have added the majority of their shell carbonate at a different location and, hence, under different environmental conditions, as they have been transported to the sampling location. This may add to the uncertainty in the variable to cross-correlate against or even introduce a bias in the resulting calibration. Recently this has been suggested for dinoflagellate cysts (Nooteboom et al., 2019) and planktonic foraminifera, collected from the water column (Ganssen and Kroon, 1991), from sediment (van Sebille et al., 2015) and also from sediment traps (Steinhardt et al., 2014), but it can also be applied to specimens collected living from the sea surface.

Here, we used a plankton pump and seawater samples collected from the Mediterranean Sea in January and February 2016 to test the viability of deconvolving salinity from combined temperature and seawater oxygen isotope reconstructions. We also investigate the potential of the newly developed salinity proxy $\mathrm{Na} / \mathrm{Ca}$ in the Mediterranean Sea. Using samples collected in winter, we also extend the calibration of $\mathrm{Mg} / \mathrm{Ca}$ to seawater temperature for G. ruber albus towards its lower temperature tolerance limits $\left(14^{\circ} \mathrm{C}\right.$; Bijma et al., 1990), which is essential for the application of this species in past seasonality reconstructions.

\section{Materials and methods}

During two cruises (NESSC cruises 64PE406 and 64PE407, RV Pelagia) between 12 January and 25 February 2016, a total of 98 plankton samples were collected from the surface waters of the Mediterranean Sea along an east-west transect using a plankton pump system (Ottens, 1992). Surface water was continuously pumped onboard from a water depth of $5 \mathrm{~m}$ and led through a plankton net with $100 \mu \mathrm{m}$ mesh size. Replacing the cod end every $6 \mathrm{~h}$ (filtering $57 \mathrm{~m}^{3}$ of seawater on average, constantly monitored using a water gauge), accumulated samples were washed out of the net into a $90 \mu \mathrm{m}$ sieve, rinsed thoroughly with deionized water to remove smaller particles and salts, and subsequently stored onboard at $-80^{\circ} \mathrm{C}$. At NIOZ, all plankton samples were then freeze-dried, and dry oxidation by low-temperature ashing $\left(100{ }^{\circ} \mathrm{C}\right)$ was used to combust the organic material while minimizing the potential impacts on carbonate trace metal concentrations and $\delta^{18} \mathrm{O}$ (Fallet et al., 2009). After ashing, samples were rinsed again thoroughly with deionized water and ethanol to remove potential ash residues. A variety of samples containing specimens of G. ruber albus (Morard et al., 2019) were selected to cover a large range of salinities and temperatures. Specimens used for analyses were selected from the size fraction between 150 and $250 \mu \mathrm{m}$, even though it has been reported that G. ruber albus and Globigerinoides elongatus cannot always be confidently distinguished at this size fraction due to similar morphology (Aurahs et al., 2011). 
Surface seawater samples for stable oxygen isotopes were collected every $60 \mathrm{~min}$ from the same pump, resulting in a set of 309 samples. A volume of $2 \mathrm{~mL}$ was stored without headspace at $4{ }^{\circ} \mathrm{C}$ during the cruise to be analysed at the home laboratory.

The elemental ratios of the final foraminiferal chamber (named the F-chamber) of individual shells were measured by laser ablation quadrupole inductively coupled plasma mass spectrometry (LA-Q-ICP-MS) using a circular spot with a diameter of $60-80 \mu \mathrm{m}$, depending on the size of the last chamber. The laser system (NWR193UC, New Wave Research) at NIOZ was used in combination with a two-volume sample cell (TV2), which allows for the detection of variability in elemental ratios within the foraminiferal chamber wall due to a short wash-out time of $1.8 \mathrm{~s}$ (van Dijk et al., 2017). Ablating only F-chambers minimizes the sampling of older carbonate that might have formed under different environmental conditions due to lateral and vertical transport. All specimens were ablated with an energy density of $1 \pm 0.1 \mathrm{~J} \mathrm{~cm}^{-2}$ and a repetition rate of $6 \mathrm{~Hz}$ in a helium environment. A $0.7 \mathrm{~L} \mathrm{~m}^{-1}$ helium flow transported the resulting aerosol to an in-house custom-built smoothing device before entering the quadrupole ICP-MS (iCAP Q, Thermo Fisher Scientific). Masses of ${ }^{7} \mathrm{Li},{ }^{11} \mathrm{~B},{ }^{23} \mathrm{Na},{ }^{24} \mathrm{Mg},{ }^{25} \mathrm{Mg}$, ${ }^{27} \mathrm{Al},{ }^{43} \mathrm{Ca},{ }^{44} \mathrm{Ca},{ }^{57} \mathrm{Fe},{ }^{88} \mathrm{Sr},{ }^{137} \mathrm{Ba}$ and ${ }^{238} \mathrm{U}$ were monitored, and $44 \mathrm{Ca}$ served as an internal standard for the quantification of the associated elements. The synthetic carbonate standard MACS-3 was used for calibration; in addition, carbonate standards JCp-1, JCt-1 and NFHS-1 (NIOZ foraminifera house standard; Mezger et al., 2016) as well as glass standards SRM NIST610 and NIST612 were used for monitoring data quality. The accuracy of the analyses was $97 \%$, while the precision was $3.0 \%$ for $\mathrm{Mg}$ and $2.4 \%$ for $\mathrm{Na}$ measurements.

Stable oxygen and carbon isotopes of foraminiferal calcite were measured on groups of whole specimens different from those used for LA-Q-ICP-MS, using an automated carbonate device (Kiel IV, Thermo Scientific) which was connected to a Thermo Finnigan MAT 253 dual-inlet isotope ratio mass spectrometer (IRMS). The NBS 19 limestone was used as a calibration standard, and the NFHS-1 standard was used for drift detection and correction. The standard deviation and offset of the NBS19 and the NFHS-1 were always within $0.1 \%$ for $\delta^{18} \mathrm{O}$.

Due to the large amount of material required (20 to $40 \mu \mathrm{g})$ and the small amount of specimens present in the samples, specimens from different samples sometimes needed to be combined. This resulted, for example, in combining 12 and $8 \mu \mathrm{g}$ of foraminifera from two adjacent transects; hence, the average temperature, salinity and $\delta^{18} \mathrm{O}$ seawater for these transects was calculated based on the relative contribution of the foraminiferal weight of the individual transects (i.e. $60 \%$ and $40 \%$ respectively). Seawater oxygen and hydrogen stable isotopes were analysed with the liquid water isotope analyser (LWIA; Los Gatos Research, Model 912-0008). This system measures the water samples using off-axis integratedcavity output spectroscopy (OA-ICOS). The LWIA was connected with a GC PAL autosampler (CTC Analytics) to inject $1 \mu \mathrm{L}$ per measurement. To achieve this, the GC PAL autosampler was equipped with a $1.2 \mu \mathrm{L}$ Hamilton syringe. Inhouse standards (S35, S45, NSW, LGR5 and double-distilled water) were calibrated against VSMOW2 (Vienna Standard Mean Ocean Water 2), VSLAP2 (Vienna Standard Light Antarctic Precipitation 2) and GISP2 (Greenland Ice Sheet Precipitation) obtained from the International Atomic Energy Agency in Vienna using the same set-up. The use of VSMOW2, which has $\delta^{18} \mathrm{O}$ values identical to the older SMOW (Standard Mean Ocean Water) standard, allows for simple comparison with older data that were calibrated using SMOW, without additional corrections. Every sample and standard was measured 14 times sequentially: the first four runs were only used to flush the system, whereas the last 10 measurements were used for the analysis. Additionally, the sample introduction line was rinsed with double-distilled water between every sample or standard. Data were processed with LGR LWIA (Los Gatos Research Liquid Water Isotope Analyzer) post processor software v. 3.0.0.88. The average standard deviation per sample was $0.14 \%$ o for oxygen isotope measurements and $0.71 \%$ o for hydrogen isotope measurements.

The likely provenance of the foraminifera sampled was computed by backtracking virtual particles in a highresolution ocean model. For this, we used the Copernicus Marine Environmental Monitoring Service (CMEMS) Global Reanalysis model. The ocean surface currents, temperature and salinity are available at a daily temporal resolution and a $1 / 12^{\circ}$ horizontal resolution. In these fields, we backtracked particles using the OceanParcels v2.1.1 software (Lange and van Sebille, 2017; Delandmeter and van Sebille, 2019). We released 10000 particles at equal spacing between the start and end locations of 25 of the transects (i.e. all for which there were sufficient foraminiferal specimens for isotope analysis), on the day these transects were sampled, and tracked the particles back for $30 \mathrm{~d}$ with a fourthorder Runge-Kutta algorithm with a $1 \mathrm{~h}$ time step, storing local temperature, salinity and location for each particle every day. To avoid beaching of particles, we used an "unbeaching kernel" similar to that in Delandmeter and van Sebille (2019). The full code of the simulations is available at https: //github.com/OceanParcels/MedForams_Daemmer/ (last access: 25 September 2020).

\section{Results}

\subsection{Mediterranean Sea geochemistry}

The sampled east-west transect spans a salinity gradient from 39.2 to 36.2 and an accompanying temperature gradient from $19^{\circ} \mathrm{C}$ (east) to $14^{\circ} \mathrm{C}$. The $6 \mathrm{~h}$ intervals represented a distance of $57 \mathrm{~km}(\min .0 \mathrm{~km}, \max .117 \mathrm{~km})$ on average. 
This resulted in an internal variability of 0.14 salinity units and $0.33^{\circ} \mathrm{C}$ for each of the 98 transects on average.

Measured seawater $\delta \mathrm{D}$ values show a range from $2.83 \%$ to $9.46 \%$ VSMOW in the western Mediterranean Sea and from $5.98 \%$ to $11.15 \%$ VSMOW in the east. Values from the individual transects were used in combination with the $\delta^{18} \mathrm{O}_{\text {water }}$ to check for internal consistency (Fig. 1). The $\delta^{18} \mathrm{O}$ values of the seawater vary between $0.13 \%$ and $2.29 \%$ VSMOW in the west and between $0.73 \%$ and $2.43 \%$ VSMOW in the east (Fig. 1). In our dataset, $\delta^{18} \mathrm{O}$ and $\delta \mathrm{D}$ of the water are positively correlated in both the western and eastern regions of the Mediterranean Sea (Fig. 1). The sensitivities of the $\delta \mathrm{D}$ to $\delta^{18} \mathrm{O}$ correlations are indistinguishable. The seawater oxygen isotopes are also linearly correlated with seawater salinity (Fig. 2) and do not show an offset between the eastern and western basins ( $p$ value $<0.001 ; R^{2}=0.17$ ).

\subsection{Foraminiferal geochemistry}

The foraminiferal oxygen isotope ratios $\left(\delta^{18} \mathrm{O}_{\text {foraminifer }}\right)$ range from $-0.41 \%$ to $0.68 \%$ and are significantly correlated with the seawater oxygen isotope ratio (Fig. 3a), albeit with much scatter $\left(R^{2}=0.42, p\right.$ value $\left.<0.001\right)$. The $\delta^{18} \mathrm{O}_{\text {foraminifer }}$ are also positively correlated with sea surface salinity (Fig. 3b), showing a similarly large amount of scatter $\left(R^{2}=0.44, p\right.$ value $\left.<0.001\right)$.

\subsection{Na / Ca vs. salinity}

$\mathrm{Na} / \mathrm{Ca}$ values measured on individual F-chambers of $G$. ruber albus from the Mediterranean Sea range from 6.8 to $12.7 \mathrm{mmol} \mathrm{mol}^{-1}$ and are positively correlated with sea surface salinity (Fig. 4a). The variability between individuals $\left(1-2 \mathrm{mmol} \mathrm{mol}^{-1}\right)$ observed within transects is orders of magnitude higher than the analytical uncertainty (RSD, relative standard deviation, of 5\%) and is also higher than the uncertainty in the slope of the $\mathrm{Na} / \mathrm{Ca}$-salinity calibration (Fig. 4a).

\subsection{Mg/Ca vs. temperature}

$\mathrm{Mg} / \mathrm{Ca}$ values measured on individual F-chambers of $G$. ruber albus from the Mediterranean Sea range from 1.34 to $7.63 \mathrm{mmol} \mathrm{mol}^{-1}$ and are positively correlated with sea surface temperatures measured in situ, although the temperature range sampled during wintertime was rather narrow (Fig. 4b).

\subsection{Particle backtracking}

Particle backtracking shows that foraminifera collected at each transect might actually have travelled long distances within the $30 \mathrm{~d}$ prior to sampling at the sample locations. The length of the modelled trajectories varies greatly from location to location, ranging between 200 and $500 \mathrm{~km}$. This resulted in a variabilities (SD, standard deviation) within one transect ranging from 0.11 to $1.0^{\circ} \mathrm{C}$ and from 0.03 to 0.4 salinity units.

\section{Discussion}

\subsection{Salinity, $\delta^{18} \mathrm{O}$ and $\delta \mathrm{D}$ of the seawater}

A single uniform and stable trend in seawater stable isotopes with salinity is a prerequisite for reconstructing past salinities. This is important not only when using the stable oxygen isotopes measured on foraminiferal shell carbonates but also for the interpretation of the hydrogen isotopic composition of alkenones, which are also used as proxies for palaeosalinity (Schouten et al., 2006; Vasiliev et al., 2013; Weiss et al., 2017).

The data presented here substantially increase the amount of data on the relation between salinity and water isotopes of the Mediterranean (Fig. 2). Although the new data clearly overlap with existing data, we also observe slight but statistically significant differences in the average salinity to $\delta^{18} \mathrm{O}$ relationship for the different datasets. The overall lower $\delta^{18} \mathrm{O}$ values of seawater measured here compared with the combined set of surface seawater isotopes from Stahl and Rinow (1973), Pierre et al. (1986), Gat et al. (1996), Pierre (1999) and Cox (2010) of approximately $0.3 \%$ (Fig. 2) may be explained by inter-decadal, seasonal and geographical variability between sample sets, or by a combination of these factors. Importantly, such offsets also give a first-order indication of the limit to the accuracy and precision of reconstructions of past salinity using a combined temperature-stable isotope approach from the primary relationship used.

Although Gat et al. (1996) reported a markedly different $\delta \mathrm{D} / \delta^{18} \mathrm{O}$ relationship for the eastern Mediterranean Sea compared with that of the western Mediterranean Sea, our results show no sign of such a longitudinal discontinuity for the same area (Fig. 2). This implies that the water isotopic composition of the entire Mediterranean Sea can primarily be described by a single mixing line between two end-members, with high vs. lower salinity respectively. The remarkable trend in $\delta \mathrm{D} / \delta^{18} \mathrm{O}$ observed previously by Gat et al. (1996) was explained as a deuterium excess effect due to a combination of the composition of the lowermost air vapour and mixing with the enriched surface waters, which is most notable in winter months. The discrepancy in the $\delta \mathrm{D} / \delta^{18} \mathrm{O}$ relationship observed between our data and those of Gat et al. (1996) may be due to inter-decadal variability in the hydrological cycle or differences in seasonal coverage. Thus, the observations of Gat et al. (1996) were potentially related to unusual conditions, spatially restricted features not covered by our sampling locations or the fact that the hydrological cycle in the eastern Mediterranean has recently changed considerably. Either way, the observed offset between the western and the eastern basins is apparently not stable and should, therefore, probably not be considered when using Mediterranean stable isotope signatures for reconstructing palaeo-salinities. 


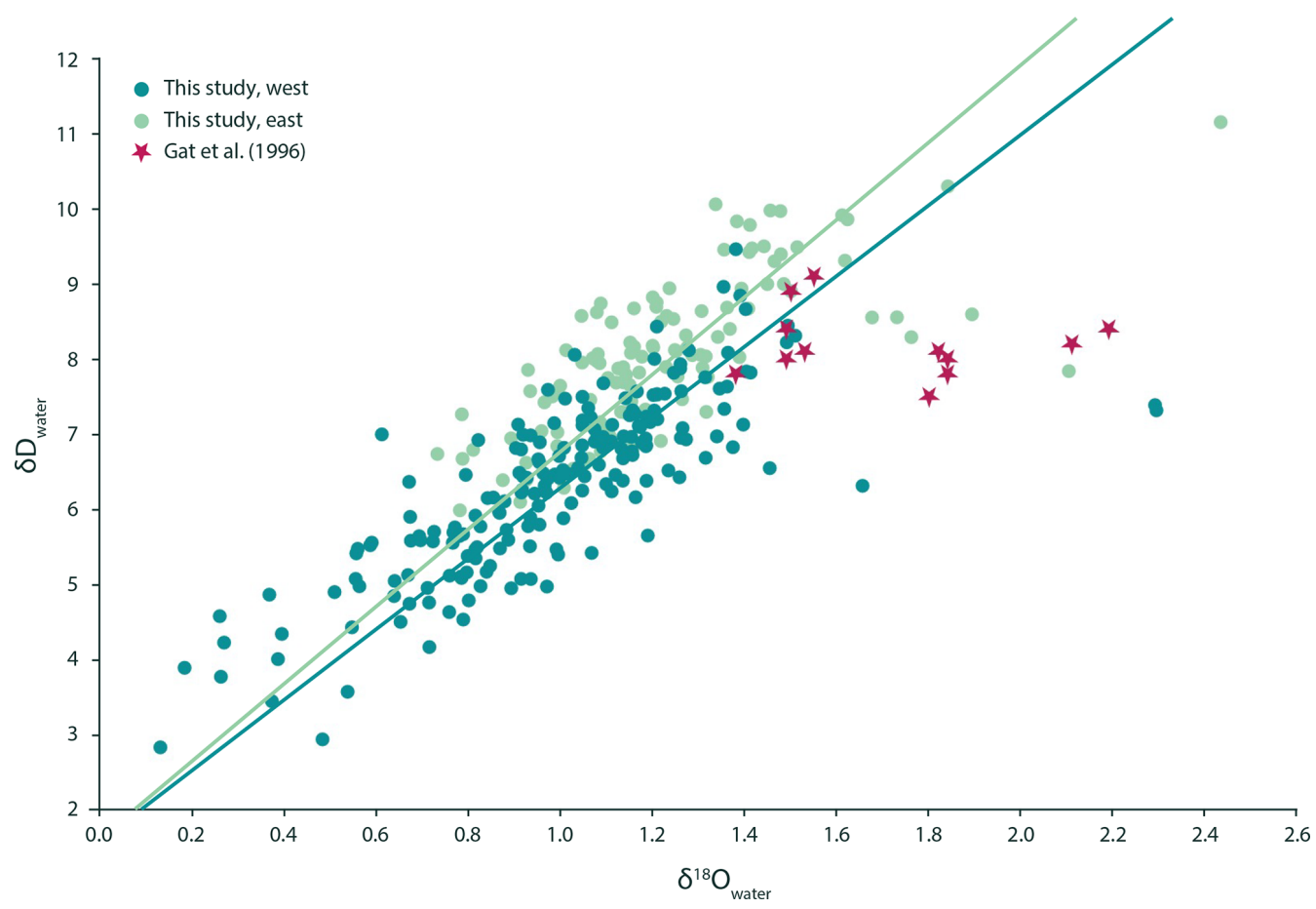

Figure 1. The $\delta \mathrm{D}$ of the Mediterranean surface seawater is positively correlated with the local $\delta^{18} \mathrm{O}$. The orthogonal regression of the western Mediterranean can be described as $\delta \mathrm{D}_{\text {water }}=4.72 \times \delta^{18} \mathrm{O}_{\text {water }}+1.67$ (dark green). The eastern Mediterranean is very similar to the western basin, and the relationship between seawater $\delta^{18} \mathrm{O}$ and $\delta \mathrm{D}$ is $\delta \mathrm{D}_{\text {water }}=5.19 \times \delta^{18} \mathrm{O}_{\text {water }}+1.68$ (light green) here. Statistically they cannot be told apart. This was determined using a bootstrapping approach that generated 100 slopes and intercepts for both the eastern and the western dataset and subsequent $t$ testing using the mean and standard deviation of both groups of slopes and intercepts, which resulted in $p$ values $>0.05$. In both areas, the relationship is different from the observations made by Gat et al. (1996), whose dataset suggested no statistically significant relationship between $\delta \mathrm{D}$ and $\delta^{18} \mathrm{O}$ of the seawater ( $p$ value $\left.>0.05\right)$.

\section{$4.2 \mathrm{Na} / \mathrm{Ca}$ vs. salinity}

The Na / Ca ratios measured on the carbonate shells of $G$. ruber albus from the Mediterranean Sea are significantly and linearly correlated with salinity (Fig. 4a). This relationship is similar to the one previously reported for plankton pumpcollected G. ruber albus from the Red Sea (Mezger et al., 2016). Mezger et al. (2016) suggested that there might a combined effect of different environmental factors such as carbonate chemistry, salinity and temperature on the $\mathrm{Na} / \mathrm{Ca}$ values in the field-collected specimens. It is not possible to decouple these factors in the Red Sea as they are strongly related. In contrast to the Red Sea where there is a strong negative correlation between salinity and temperature, the Mediterranean sea surface salinity and temperature are positively correlated with each other; thus, comparing our data to that of Mezger et al. (2016) allows for the temperature to be decoupled from salinity (Fig. 5). This shows that the correlation between foraminiferal $\mathrm{Na} / \mathrm{Ca}$ values and temperature observed in the Red Sea was not causal and was more likely caused by salinity (Mezger et al., 2016). If temperature would have a significant effect on the $\mathrm{Na} / \mathrm{Ca}$ values in G. ruber albus, we would expect different slopes and/or offsets for the $\mathrm{Na} / \mathrm{Ca}$ to salinity calibrations for the Mediter- ranean Sea and Red Sea. This implies that temperature has no or only a minor impact on $\mathrm{Na} / \mathrm{Ca}$ ratios in G. ruber albus shells, which is in line with similar findings that have shown a lack of a temperature effect on the $\mathrm{Na} / \mathrm{Ca}$ of $T$. sacculifer (Bertlich et al., 2018). The average standard deviation in $\mathrm{Na} / \mathrm{Ca}$ values for a given salinity corresponds approximately to 2 salinity units, using the calibration given here (Fig. 4a). This large variability is similar to the inter-chamber and inter-specimen variability in other $\mathrm{El} / \mathrm{Ca}$ ratios, such as in $\mathrm{Mg} / \mathrm{Ca}$ reported by Sadekov et al. (2008), and appears to be inherent to single-chamber $\mathrm{El} / \mathrm{Ca}$ (de Nooijer et al., 2014b). It has been suggested that such variability between individuals and also between different chambers of the same individual may be caused by differences in the living depth and, hence, environmental conditions (Mezger et al., 2018), lateral transport (van Sebille et al., 2015) or variability in element incorporation during biomineralization due to vital effects (Erez, 2003; de Nooijer et al., 2014a; Spero et al., 2015), or individual timing of chamber formation (Dämmer et al., 2019). As the specimens used here were collected from surface waters and add new chambers very frequently, vertical or lateral migration into waters with significantly different conditions as suggested by Mezger et al. (2018) and Van 


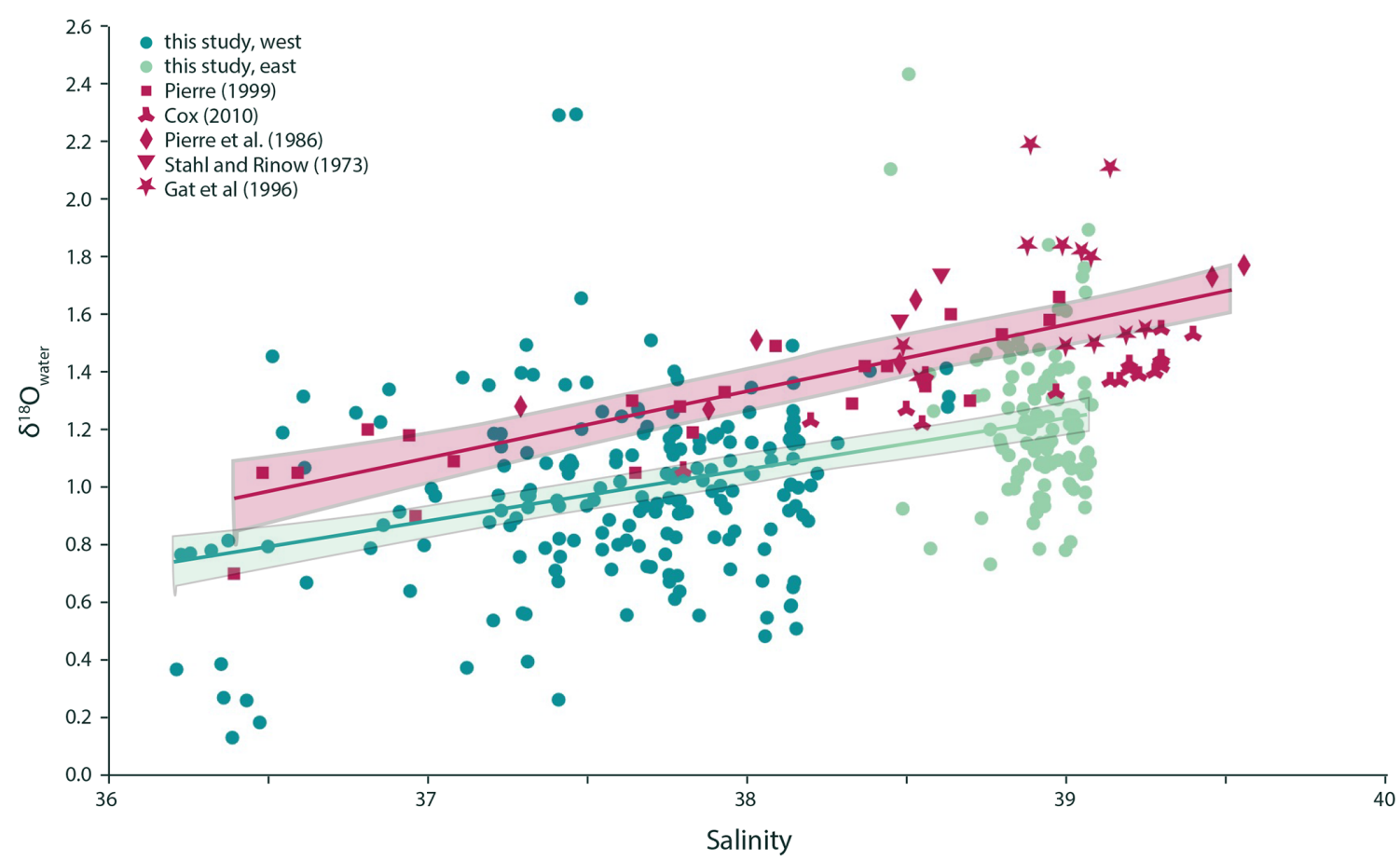

Figure 2. Surface seawater $\delta^{18} \mathrm{O}$ is positively correlated with sea surface salinity in the Mediterranean Sea, and the relationship observed can be described as linear regression $\delta^{18} \mathrm{O}_{\text {water }}=0.17 \times S-5.39$ ( $p$ value $<0.001$, adjusted $R^{2}=0.17$ ). Previously published data can be combined into one dataset with a similar relationship with a slightly steeper slope, which is offset towards relatively higher $\delta^{18} \mathrm{O}$ $\left(\delta^{18} \mathrm{O}_{\text {water }}=0.22 \times S-7.19 ; p\right.$ value $<0.001$, adjusted $\left.R^{2}=0.48\right)$. The two regression lines are significantly different from each other (ANOVA $p$ value $<0.01$ ).
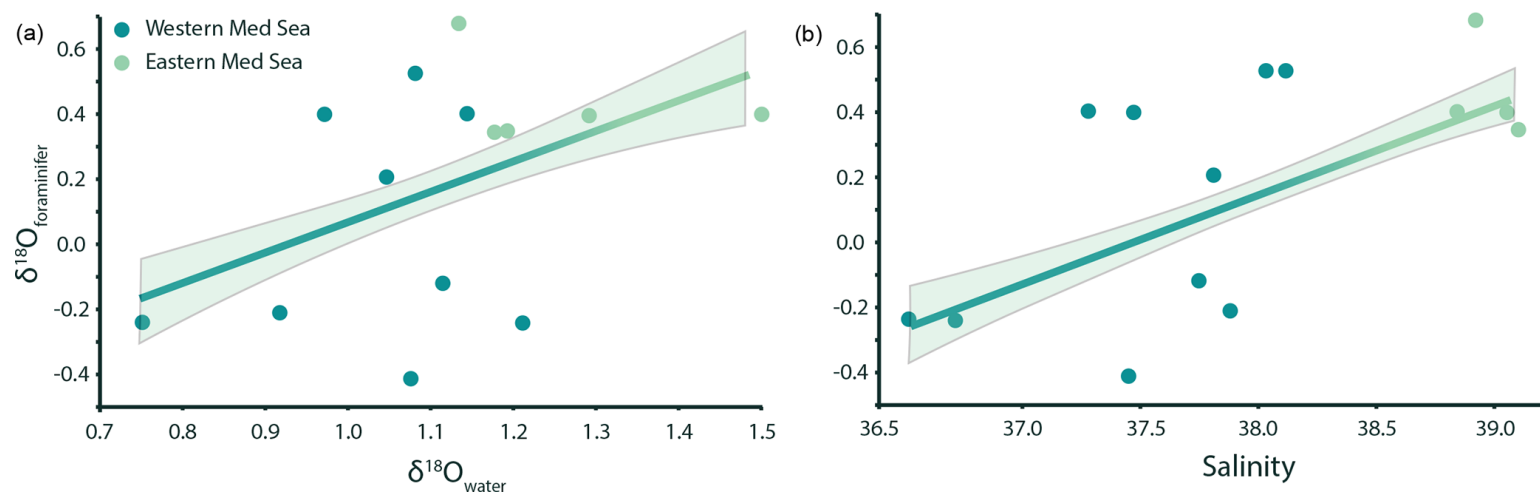

Figure 3. G. ruber albus $\delta^{18} \mathrm{O}$ measurements are positively correlated ( $p$ value $<0.001$ ) with both seawater $\delta^{18} \mathrm{O}$ (a) and salinity (b). The relationships can be described using the following equations: $\delta^{18} \mathrm{O}_{\text {foraminifer }}=0.28 \times S-10.59$ (adjusted $\left.R^{2}=0.42\right)$ and $\delta^{18} \mathrm{O}_{\text {foraminifer }}=$ $0.95 \times \delta^{18} \mathrm{O}_{\text {water }}-0.89$ (adjusted $R^{2}=0.24$ ). The relationship between $\delta^{18} \mathrm{O}_{\text {water }}$ and salinity in this subset of samples is linear and comparable to that of the entire dataset $\left(\delta^{18} \mathrm{O}_{\text {water }}=0.13 \times S-3.91 ; p\right.$ value $\left.<0.05, R^{2}=0.37\right)$.

Sebille et al. (2015) appears to be an unlikely cause of heterogeneity between specimens in this case. The relatively large scatter in the $\mathrm{Na} / \mathrm{Ca}$ values observed for single chambers (Fig. 4a) implies that accurate and precise reconstructions of salinity can only be based on combining a substantial number of specimens (Wit et al., 2013).

If salinity is reconstructed from the $\mathrm{Na} / \mathrm{Ca}$ measurements using the calibration published by Mezger et al. (2016) and compared to salinity measured in situ in the Mediterranean Sea, the reconstructed salinity follows the in situ measurements closely, almost $1: 1$. The largest deviation from this $1: 1$ relationship occurs in the lower salinity range: at a salinity of 36.52 , the reconstructed salinity estimates underestimate in situ salinity values by 0.71 salinity units. The average difference between in situ salinity measurements and salinity reconstructed based on one single-chamber measure- 

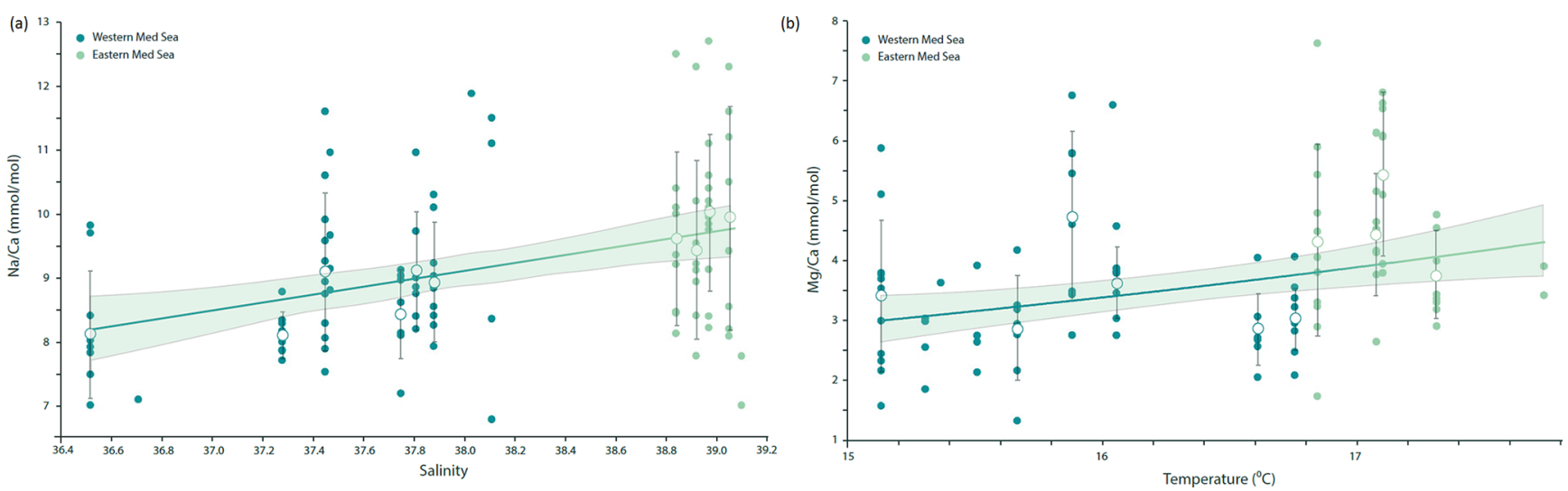

Figure 4. (a) $\mathrm{Na} / \mathrm{Ca}$ measured in G. ruber albus F-chambers collected as living specimens from the eastern and western Mediterranean Sea correlates well with local salinity ( $p$ value $<0.001, \mathrm{Na} / \mathrm{Ca}=0.60 \times S-13.84$ ), even though a large natural spread of the elemental composition around the mean values per station exists $\left(R^{2}=0.13\right)$. For salinities with more than five individual Na / Ca measurements, hollow circles with whiskers indicate average values and standard deviations respectively. (b) $\mathrm{Mg} / \mathrm{Ca}$ in F-chambers of G. ruber albus specimens collected from the water column of the Mediterranean Sea is positively correlated with sea surface temperature and can be described with the following exponential relationship: $\mathrm{Mg} / \mathrm{Ca}=0.37 \times \exp (0.14 \times T)$. For temperatures with more than five individual $\mathrm{Mg} / \mathrm{Ca}$ measurements, hollow circles with whiskers indicate average values and standard deviations respectively. Regression lines were calculated using all individual data points.

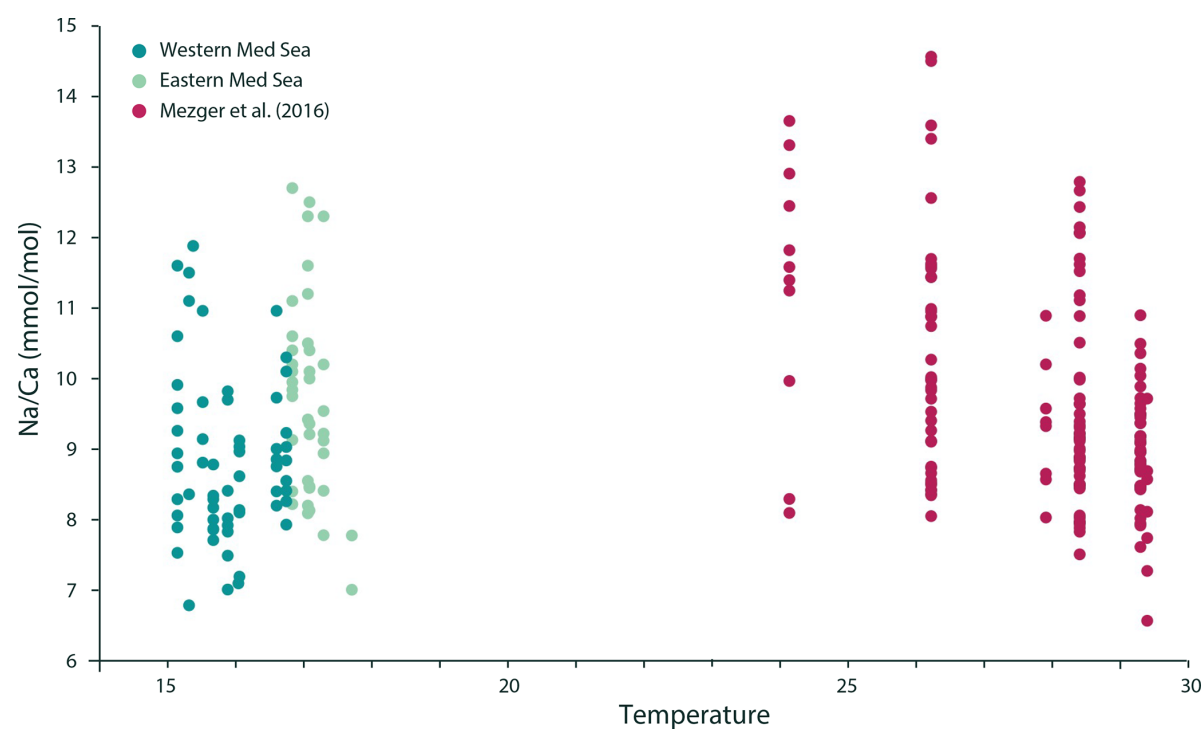

Figure 5. The ratio of $\mathrm{Na} / \mathrm{Ca}$ in G. ruber albus appears to be independent of seawater temperature. While Mezger et al. (2016) showed a negative relationship between temperature and foraminiferal $\mathrm{Na} / \mathrm{Ca}$ in specimens collected from the Red Sea, the addition of new data from the Mediterranean Sea clearly shows that the previously hypothesized negative impact of temperature on $\mathrm{Na} / \mathrm{Ca}$ is likely an artefact of the negative relationship of temperature and salinity in the Red Sea and that temperature has no significant impact on $\mathrm{Na} / \mathrm{Ca}$.

ment is an underestimation of salinity by 0.46 salinity units. This is still higher than the theoretical uncertainty associated with combining foraminiferal $\delta^{18} \mathrm{O}$ and temperatures derived from $\mathrm{Mg} / \mathrm{Ca}$ measured for exactly the same specimens (Rohling, 2007). An uncertainty (1SD) of $1^{\circ} \mathrm{C}$ in the $\mathrm{Mg} / \mathrm{Ca}-$ temperature calibration (which may be particularly optimistic at high seawater temperatures) would result in an uncertainty of $\sim 0.37$ units for the reconstructed difference between the two salinities. This approach would lead to an improved salinity reconstruction when the (change in) past temperatures are determined more precisely, for example, by reducing the error through increased sample size. The same applies for salinity reconstructions based on $\mathrm{Na} / \mathrm{Ca}$, for which a limited number of calibrations are available, and, hence, leaves room for improvement.

While these reconstructions and the lack of a strong temperature effect are very encouraging results for the use of $\mathrm{Na} / \mathrm{Ca}$ as a salinity proxy, the incorporation of $\mathrm{Na}$ into 


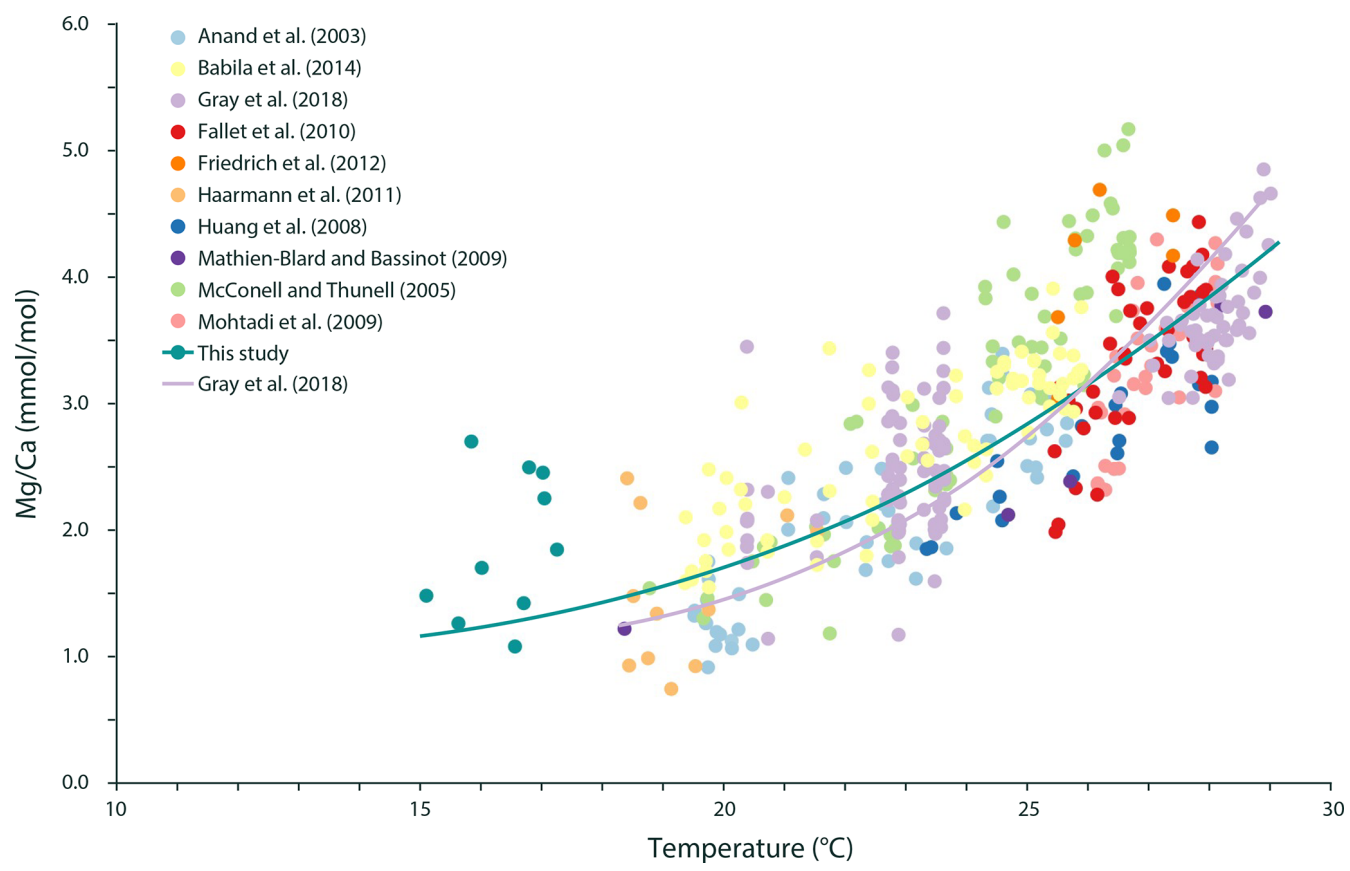

Figure 6. The relationship between $\mathrm{Mg} / \mathrm{Ca}$ in $\mathrm{G}$. ruber albus and temperature during calcification can be described using the following exponential equation for a temperature range from 15.1 to $29.1^{\circ} \mathrm{C}: \mathrm{Mg} / \mathrm{Ca}=0.278 \times \exp (0.093 \times T)$.

foraminiferal calcite does not appear to be homogenous across the entire shell. It has been shown that the majority of $\mathrm{Na}$ in G. ruber albus is located in the spines (Mezger et al., 2018, 2019), which are not well preserved in the fossil record.

\subsection{G. ruber albus $\mathrm{Mg} / \mathrm{Ca}$ values}

The increase in $\mathrm{Mg} / \mathrm{Ca}$ in G. ruber albus with temperature (Fig. 4b) fits recent calibration efforts for Mg incorporation and for temperature (e.g. Gray et al., 2018). As salinity and inorganic carbon chemistry also both affect $\mathrm{Mg}$ incorporation in this species (Kisakürek et al., 2008; Gray et al., 2018), and the Mediterranean exhibits large gradients in these parameters, it is necessary to correct measured $\mathrm{Mg} / \mathrm{Ca}$ values for these parameters. After normalizing $\mathrm{Mg} / \mathrm{Ca}$ values to a seawater salinity of 35 , using the calibration of Gray et al. (2018), the dependency of the $\mathrm{Mg} / \mathrm{Ca}$ on temperature is similar to previously reported calibrations (e.g. Gray et al., 2018), although the $\mathrm{Mg} / \mathrm{Ca}$ values at the lowermost temperatures appear to be higher than expected (Fig. 6). This could potentially be caused by a combination of an underestimation of the salinity effect in these highly saline waters, as salinities observed here are well outside the calibration range used by Gray et al. (2018), and low temperatures, which have comparatively little impact on the foraminiferal $\mathrm{Mg} / \mathrm{Ca}$.

Adding our results to published $\mathrm{Mg} / \mathrm{Ca}$-temperature calibrations for G. ruber albus (Anand et al., 2003; Babila et al., 2014; Fallet et al., 2010; Friedrich et al., 2012; Gray et al., 2018; Haarmann et al., 2011; Huang et al., 2008; Kisakürek et al., 2008; Mathien-Blard and Bassinot, 2009; McConnell and Thunell, 2005; Mohtadi et al., 2009) now extends the combined calibration to lower temperatures (i.e. $<18^{\circ} \mathrm{C}$ ), maintaining a comparatively low temperature sensitivity in the colder part of the calibration (Fig. 6). This not only increases confidence in the application of $\mathrm{Mg} / \mathrm{Ca}$ in this species as a palaeo-temperature reconstruction tool for colder temperatures but also supports the application of individual foraminiferal $\mathrm{Mg} / \mathrm{Ca}$ values for reconstructing seasonality (Wit et al., 2010). Although low densities have previously been reported for G. ruber albus in the Mediterranean Sea during wintertime, including their absence in large areas $(\mathrm{Pu}-$ jol and Grazzini, 1995; Bárcena et al., 2004), our finding implies that the lowest $\mathrm{Mg} / \mathrm{Ca}$ values can be related to winter temperatures. G. ruber albus is not only present throughout the year, as also shown by Rigual-Hernández et al. (2012) and Avnaim-Katav et al. (2020), but it also registers the in situ temperature, even during seasons that are close to its lower temperature limit. Admittedly, the large scatter also observed at one single sampling time (i.e. season) makes the deconvolution of seasonality from analysing single specimen $\mathrm{Mg} / \mathrm{Ca}$ values challenging.

\section{$4.4 \delta^{18} \mathrm{O}_{\text {foraminifer }}$}

\subsubsection{Role of lateral transport on $\delta^{18} \mathrm{O}_{\text {foraminifer }}$}

The horizontal transport of planktonic foraminifera may increase their exposure to variable environmental conditions, including different temperatures, salinities and seawater sta- 
a)

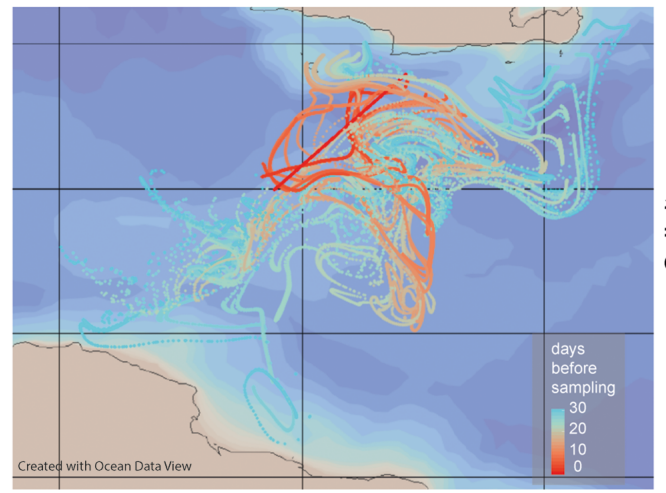

b) 39.25

39.00

竞

38.50

38.25

avg backtracked $\mathrm{T}=17.88 \pm 0.75$

avg backtracked $S=39.01 \pm 0.20$

17

$18 \quad 19$

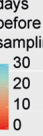

20

c)

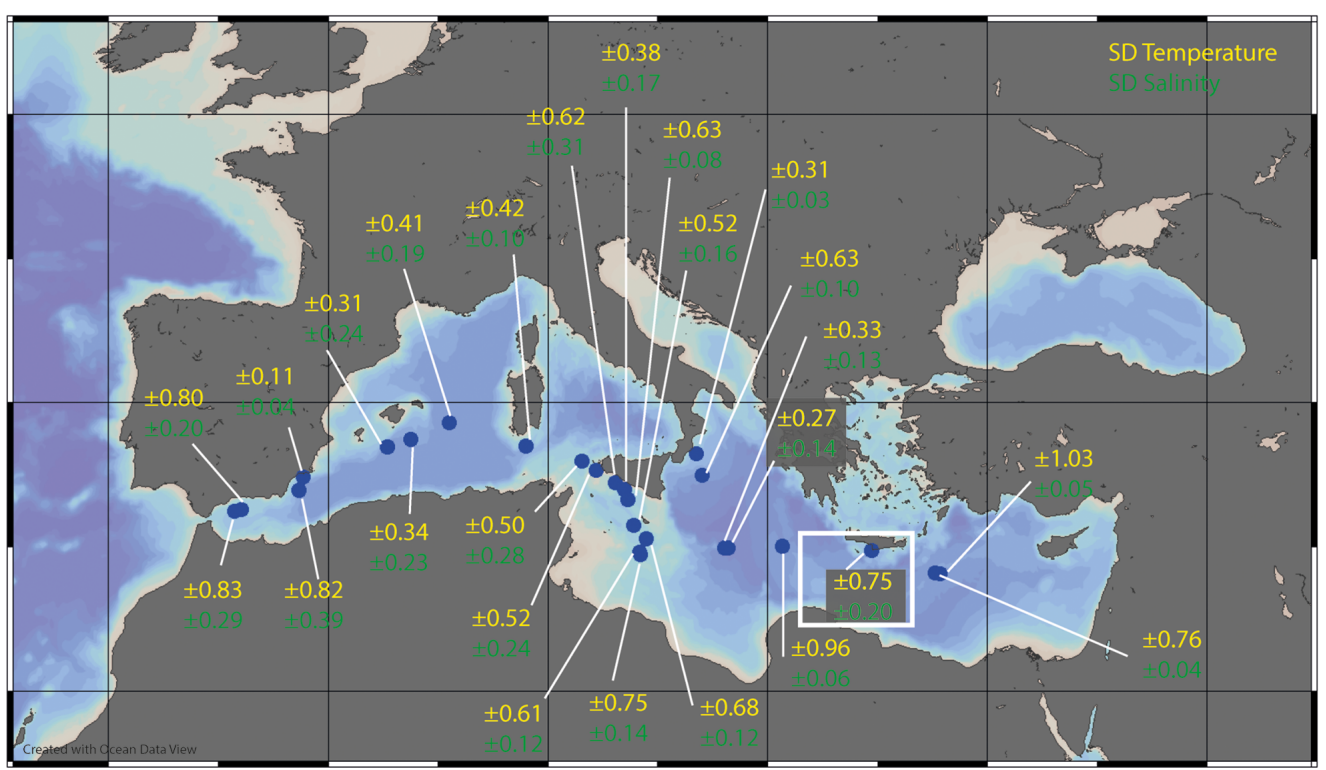

Figure 7. (a) Example of backtracked pathways for a single transect (the area marked using a white rectangle in panel c). The colour indicates the time before sampling up to $30 \mathrm{~d}$. (b) Analysing the different environmental conditions at the different locations of these potential paths shows that the foraminifera sampled very likely experienced a large range of temperatures and salinities. (c) The variability in the potential environmental conditions experienced changes considerably from location to location, as indicated by notation of 1 standard deviation for both parameters for each sampling location. The maps in panels (a) and (c) were generated using Ocean Data View version 4.

ble isotope compositions (van Sebille et al., 2015). Comparing the sampled transects with the calculated backtracking trajectories shows that the area where the foraminifera might be derived from, especially close to the straits (Alboran Sea and Strait of Sicily), potentially extends over considerable distances and, therefore, encompasses considerable variability with respect to environmental parameters. Due to the surface variability in temperature and salinity during the sampling period, the calculated variability in these parameters varied between 0.11 and $1.03^{\circ} \mathrm{C}$ per transect and 0.04 and 0.39 salinity units per transect (Fig. $7 b, c)$. This means that the majority of foraminifera experienced a variability of approximately $0.5^{\circ} \mathrm{C}$ and 0.15 salinity units.

When considering calibrations, this does not affect the measured proxy variables, as the difference may be unbiased, but it adds to the uncertainty of the environmental param- eter to be reconstructed. As foraminifera grow by periodically adding chambers and as the size of the added chambers increases exponentially in many species, the carbonate added closer to the sampling location makes up a larger proportion of the total shell mass than carbonate added at earlier life stages. Therefore, chambers formed early during a foraminifer's life have less impact on the average shell composition; hence, the calibration and the backtracking trajectories (Fig. 7a-c) indicate the largest possible range of conditions experienced by a single foraminifer. This is relevant when considering whole-shell chemistry (i.e. oxygen isotopes; Fig. 4a) and, to a lesser extent, when considering the elemental composition of the final chamber (Fig. 4b). The last chamber is affected by a much smaller range of environmental conditions, i.e. only the time span during which the 


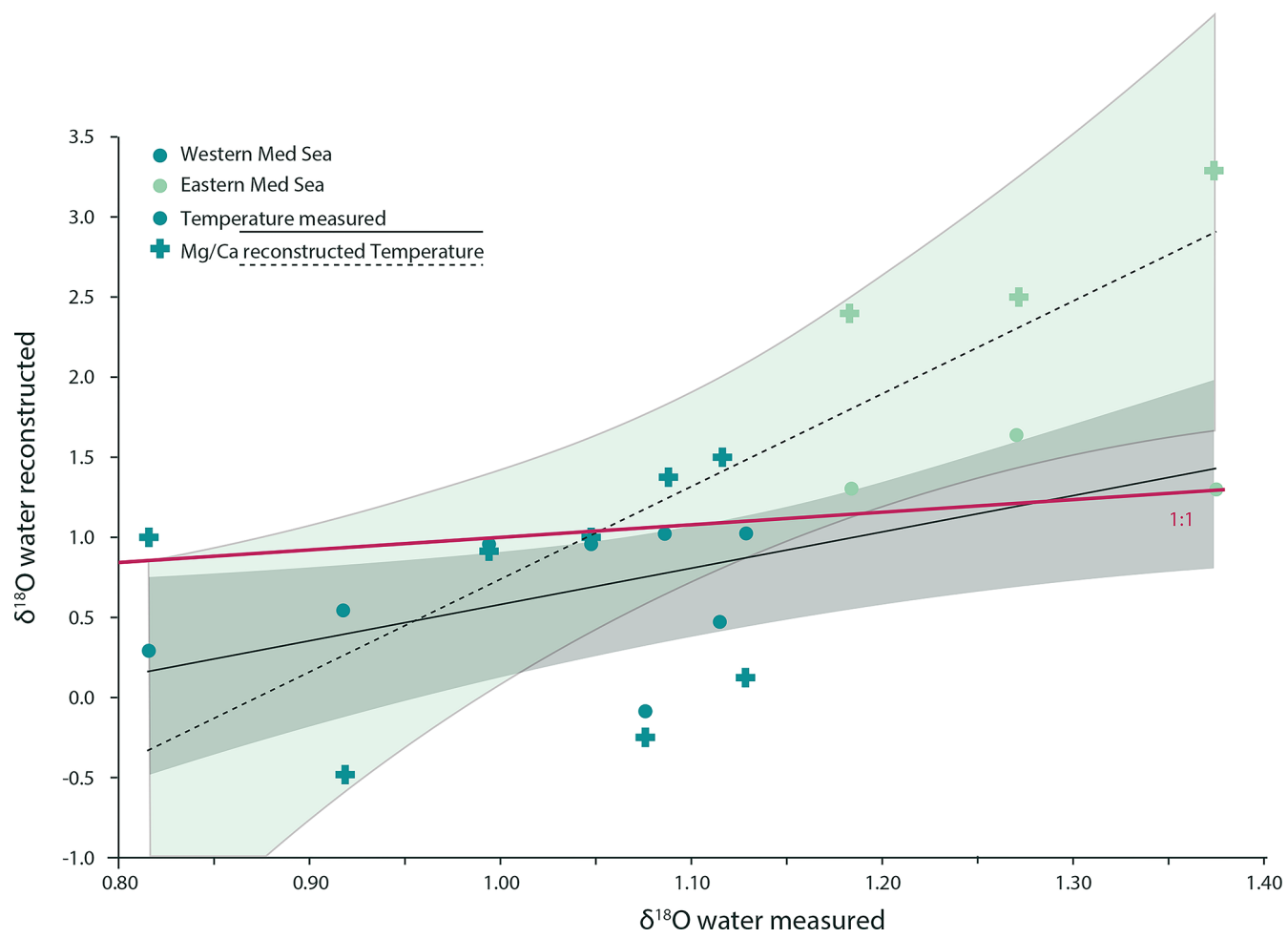

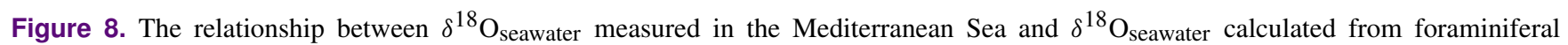
geochemistry (G. ruber albus). The relationship shown with dashed lines and cross-shaped markers represents values calculated using foraminiferal $\delta^{18} \mathrm{O}$ as well as $\mathrm{Mg} / \mathrm{Ca}$ as an additional temperature proxy to decouple the effect of temperature and salinity on $\delta^{18} \mathrm{O}$. The relationship shown with the continuous lines and circular markers shows the same samples; however, instead of using temperature values derived from foraminiferal $\mathrm{Mg} / \mathrm{Ca}$ ratios, in situ measurements for temperature were used, and the relationship can be described as $\delta^{18} \mathrm{O}_{\text {water_reconstructed }}=2.62( \pm 0.69) \times \delta^{18} \mathrm{O}_{\text {water_measured }}-63.99( \pm 26.11)$ with an adjusted $R^{2}$ of 0.37 . The temperature gradient was $2.2^{\circ} \mathrm{C}$.

final chamber was built - not more than a few days prior to sampling.

Because $\delta^{18} \mathrm{O}$ of the calcite could not be measured on $\mathrm{F}$ chambers alone, as for element / Ca ratios, and several specimens were needed for a single analysis, the results reflect the average composition of foraminiferal populations at the sampling areas. The averaging effectively cancels out differences due to inter- and intra-individual variability but not offsets due to lateral transport. When transport directions are largely uniform, this result in biases and should not add to the scatter in the calcite's isotope composition. Hence, this transport affects the calibration, but it does not affect precision.

\subsubsection{Implications for proxies}

Combining existing calibrations for foraminiferal $\mathrm{Mg} / \mathrm{Ca}$ and temperature (Gray et al., 2018) and calibrations relat-

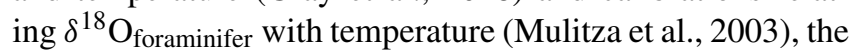
$\delta^{18} \mathrm{O}_{\text {seawater }}$ can be calculated. Using our dataset, we assess the quality of such reconstructions by comparison to measured $\delta^{18} \mathrm{O}_{\text {seawater }}$ (Fig. 8). The $\mathrm{Mg} / \mathrm{Ca}$ values used here were not corrected for salinity effects, as salinity is the target parameter that has to be reconstructed and is, thus, treated as unknown. Even though there is a carbonate ion effect on the $\mathrm{Mg} / \mathrm{Ca}$ in G. ruber albus (Evans et al., 2016; Gray et al., 2018; Kisakürek et al., 2008), the measured values were not corrected for this, as this factor is also unknown in palaeoreconstructions.

Calculated and measured $\delta^{18} \mathrm{O}_{\text {seawater }}$ do not follow a $1: 1$ correspondence; this could be caused by uncertainties in the different proxy calibrations, analytical uncertainties, the heterogeneous element and isotope composition within and between specimens; variability in the location and timing of their calcification; and the effect of salinity and $\mathrm{pH}$ on $\mathrm{Mg} / \mathrm{Ca}$. The lack of a strong correlation between calculated and measured $\delta^{18} \mathrm{O}_{\text {seawater }}$ in our dataset implies that calculating salinity from reconstructed $\delta^{18} \mathrm{O}_{\text {seawater values }}$ will not yield meaningful salinity reconstructions, as reconstructed values for $\delta^{18} \mathrm{O}_{\text {seawater }}$ are not well correlated with $\delta^{18} \mathrm{O}_{\text {seawater }}$ measured in situ. Calculating salinities from $\delta^{18} \mathrm{O}_{\text {seawater }}$ clearly adds much uncertainty due to spatial and temporal variability in the correlation of these two parameters (Conroy et al., 2017; LeGrande and Schmidt, 2006; McConnell et al., 2009). 
It is important to note that the scatter in the foraminiferal chemistry can only be explained by lateral transport to a small degree (Fig. 7). This effect may be larger in areas where the environmental conditions vary more strongly over the distance travelled by the foraminifer and/or in basins where there is simply more lateral transport over the foraminifers' lifetime. In our exercise, the calculated trajectories add only a minor component to the uncertainty in $T$ (often within $0.75^{\circ} \mathrm{C}$; Fig. 7) and salinity (often within 0.25 salinity units).

In our dataset, the uncertainty in salinity estimates based on $\delta^{18} \mathrm{O}_{\text {seawater }}$ is much smaller when using temperatures measured in situ (Fig. 8). The sum of squares of the residuals (the difference between reconstructed and measured values) is 9.04 when using temperatures derived from $\mathrm{Mg} / \mathrm{Ca}$ and $\delta^{18} \mathrm{O}_{\text {foraminifer }}$ but only 3.56 when using temperatures measured in situ, indicating a better reconstruction.

This shows that the uncertainty or offset in temperatures derived from $\mathrm{Mg} / \mathrm{Ca}$, although the $\mathrm{Mg} / \mathrm{Ca}$-temperature relationship has been studied relatively extensively for $G$. ruber albus, is most likely the most limiting step. Even though temperatures reconstructed from $\mathrm{Mg} / \mathrm{Ca}$ in our dataset deviated less than $2{ }^{\circ} \mathrm{C}$ from the measured temperature, these small offsets have a large effect on the reconstructed $\delta^{18} \mathrm{O}_{\text {seawater. }}$. Thus, it is crucial to choose temperature proxies carefully, use a large enough number of specimens for analysis, be aware of the potential effects of lateral particle transport as well as other environmental parameters, and to be conscious about how errors propagate in palaeoclimate reconstructions.

Combining all foraminiferal shell chemistry results show that salinities based on $\delta^{18} \mathrm{O}$ and $\mathrm{Mg} / \mathrm{Ca}$ may allow for the calculation of past salinity under some specific conditions, but the uncertainties in $\delta^{18} \mathrm{O}_{\text {seawater }}$ are large, even in a setting with a large salinity gradient such as the Mediterranean Sea. This is in line with predictions of uncertainty based on theoretical considerations (Rohling, 2007). The most limiting step in these calculations is the reconstruction of past temperatures, which should be better than $2^{\circ}$. Therefore, the development, validation and improvement of other, more direct salinity proxies such as foraminiferal $\mathrm{Na} / \mathrm{Ca}$ remains crucial for more reliable palaeo-salinity reconstructions.

\section{Conclusions}

Using plankton pump samples from the Mediterranean Sea, we showed the following:

1. The relationship of $\mathrm{Mg} / \mathrm{Ca}$ in G. ruber albus and seawater temperature at lower temperatures follows an exponential relationship; therefore, the proxy can now be applied to lower temperature ranges $\left(<18^{\circ} \mathrm{C}\right)$ than before, covering almost the entire temperature tolerance range of that species, although the sensitivity of the calibration is comparatively low at low temperatures.
2. The combination of foraminiferal $\delta^{18} \mathrm{O}$ and $\mathrm{Mg} / \mathrm{Ca}$ along with assumptions about $\delta^{18} \mathrm{O}_{\text {seawater values and }}$ $\delta^{18} \mathrm{O}_{\text {seawater-salinity relationships does not lead to use- }}$ ful reconstructions of seawater salinity.

3. Foraminiferal $\mathrm{Na} / \mathrm{Ca}$ correlates well with sea surface salinity and is independent of temperature, making it a potentially valuable tool for salinity reconstructions.

Data availability. Upon publication, the data on which this paper is based will be available at the 4TU.Centre for Research Data (https://doi.org/10.4121/13246616.v1, de Nooijer et al., 2020.).

Author contributions. LKD, LdN and GJR designed the study and performed the sample collection. LKD and JGH prepared and processed the samples and the corresponding data. EvS performed the particle backtracking. All authors were involved in data interpretation. LKD drafted the paper with contributions from all authors.

Competing interests. The authors declare that they have no conflict of interest.

Acknowledgements. We thank the editor as well as Michal Kucera and a second, anonymous referee for their comments and suggestions that helped to improve this paper. We thank the captain, crew and scientific staff of RV Pelagia NESSC cruises 64PE406 and 64PE407, especially Anne Roepert (Utrecht University) who collected the majority of the seawater samples used in this study. We also thank Sharyn Ossebaar, Piet van Gaever and Wim Boer (NIOZ) for their vital technical assistance as well as Geert-Jan A. Brummer (NIOZ/Vrije Universiteit Amsterdam) for his support during sample preparation and many discussions.

Financial support. This research has been supported by the NESSC.

Review statement. This paper was edited by Alessio Rovere and reviewed by Michal Kucera and one anonymous referee.

\section{References}

Allen, K. A., Hönisch, B., Eggins, S. M., Haynes, L. L., Rosenthal, Y., and Yu, J.: Trace element proxies for surface ocean conditions: A synthesis of culture calibrations with planktic foraminifera, Geochim. Cosmochim. Ac., 193, 197-221, https://doi.org/10.1016/j.gca.2016.08.015, 2016.

Allison, N., Austin, H., Austin, W., and Paterson, D. M.: Effects of seawater $\mathrm{pH}$ and calcification rate on test $\mathrm{Mg} / \mathrm{Ca}$ and $\mathrm{Sr} / \mathrm{Ca}$ in cultured individuals of the benthic, calcitic foraminifera Elphidium williamsoni, Chem. Geol., 289, 171178, https://doi.org/10.1016/j.chemgeo.2011.08.001, 2011. 
Anand, P., Elderfield, H., and Conte, M. H.: Calibration of $\mathrm{Mg} / \mathrm{Ca}$ thermometry in planktonic foraminifera from a sediment trap time series, Paleoceanography, 18, 1050, https://doi.org/10.1029/2002PA000846, 2003.

Aurahs, R., Treis, Y., Darling, K., and Kucera, M.: A revised taxonomic and phylogenetic concept for the planktonic foraminifer species Globigerinoides ruber based on molecular and morphometric evidence, Mar. Micropaleontol., 79, 1-14, https://doi.org/10.1016/j.marmicro.2010.12.001, 2011.

Avnaim-Katav, S., Herut, B., Rahav, E., Katz, T., Weinstein, Y., Alkalay, R., Berman-Frank, I., Zlatkin, O., and Almogi-Labin, A.: Sediment trap and deep sea coretop sediments as tracers of recent changes in planktonic foraminifera assemblages in the southeastern ultra-oligotrophic Levantine Basin, Deep-Sea Res. Pt. II, 171, 104669, https://doi.org/10.1016/j.dsr2.2019.104669, 2020.

Babila, T. L., Rosenthal, Y., and Conte, M. H.: Evaluation of the biogeochemical controls on B / Ca of Globigerinoides ruber white from the Oceanic Flux Program, Bermuda, Earth Planet. Sc. Lett., 404, 67-76, https://doi.org/10.1016/j.eps1.2014.05.053, 2014.

Bahr, A., Schönfeld, J., Hoffmann, J., Voigt, S., Aurahs, R., Kucera, M., Flögel, S., Jentzen, A., and Gerdes, A.: Comparison of $\mathrm{Ba} / \mathrm{Ca}$ and $\delta 180$ water as freshwater proxies: A multi-species core-top study on planktonic foraminifera from the vicinity of the Orinoco River mouth, Earth Planet. Sc. Lett., 383, 45-57, https://doi.org/10.1016/j.epsl.2013.09.036, 2013.

Bárcena, M. A., Flores, J. A., Sierro, F. J., Pérez-Folgado, M., Fabres, J., Calafat, A., and Canals, M.: Planktonic response to main oceanographic changes in the Alboran Sea (Western Mediterranean) as documented in sediment traps and surface sediments, Mar. Micropaleontol., 53, 423-445, https://doi.org/10.1016/j.marmicro.2004.09.009, 2004.

Bertlich, J., Nürnberg, D., Hathorne, E. C., de Nooijer, L. J., Mezger, E. M., Kienast, M., Nordhausen, S., Reichart, G.-J., Schönfeld, J., and Bijma, J.: Salinity control on Na incorporation into calcite tests of the planktonic foraminifera Trilobatus sacculifer - evidence from culture experiments and surface sediments, Biogeosciences, 15, 5991-6018, https://doi.org/10.5194/bg-15-5991-2018, 2018.

Bijma, J., Faber, W. W., and Hemleben, C.: Temperature and salinity limits for growth and survival of some planktonic foraminifers in laboratory cultures, J. Foraminifer. Res., 20, 95116, https://doi.org/10.2113/gsjfr.20.2.95, 1990.

Conroy, J. L., Thompson, D. M., Cobb, K. M., Noone, D., Rea, S., and Legrande, A. N.: Spatiotemporal variability in the $\delta^{18} \mathrm{O}$-salinity relationship of seawater across the tropical Pacific Ocean, Paleoceanography, 32, 484-497, https://doi.org/10.1002/2016PA003073, 2017.

Cox, K.: Stable Isotopes as Tracers for Freshwater Fluxes into the North Atlantic, Doctoral Thesis, University of Southampton, Southampton , UK, 178 pp., 2010.

Dämmer, L. K., Nooijer, L. J. De and Reichart, G. J.: Light Impacts $\mathrm{Mg}$ Incorporation in the Benthic Foraminifer Amphistegina lessonii, Front. Mar. Sci., 6, 1-8, https://doi.org/10.3389/fmars.2019.00473, 2019.

Delandmeter, P. and van Sebille, E.: The Parcels v2.0 Lagrangian framework: new field interpolation schemes, Geosci. Model Dev., 12, 3571-3584, https://doi.org/10.5194/gmd-123571-2019, 2019. de Nooijer, L. J., Spero, H. J., Erez, J., Bijma, J., and Reichart, G. J.: Biomineralization in perforate Foraminifera, Earth-Sci. Rev., 135, 48-58, https://doi.org/10.1016/j.earscirev.2014.03.013, 2014a.

de Nooijer, L. J., Hathorne, E. C., Reichart, G. J., Langer, G., and Bijma, J.: Variability in calcitic $\mathrm{Mg} / \mathrm{Ca}$ and $\mathrm{Sr} / \mathrm{Ca}$ ratios in clones of the benthic foraminifer Ammonia tepida, Mar. Micropaleontol., 107, 32-43, https://doi.org/10.1016/j.marmicro.2014.02.002, 2014b.

de Nooijer, L., Daemmer, L., van Sebille, E., Haak, J., and Reichart, G.-J.: Data belonging to the publication "Evaluation of oxygen isotopes and trace elements in planktonic foraminifera from the Mediterranean Sea as recorders of seawater oxygen isotopes and salinity", Dataset, 4TU.ResearchData, https://doi.org/10.4121/13246616.v1, 2020.

Dueñas-Bohórquez, A., Raitzsch, M., de Nooijer, L. J., and Reichart, G.-J.: Independent impacts of calcium and carbonate ion concentration on $\mathrm{Mg}$ and $\mathrm{Sr}$ incorporation in cultured benthic foraminifera, Mar. Micropaleontol., 81, 122-130, https://doi.org/10.1016/j.marmicro.2011.08.002, 2011.

Erez, J.: The source of ions for biomineralization in foraminifera and their implications for paleoceanographic proxies (Review), Rev. Mineral. Geochem., 54, 115, https://doi.org/10.2113/0540115, 2003.

Elderfield, H. and Ganssen, G.: Past temperature and $\delta 18 \mathrm{O}$ of surface ocean waters inferred from foraminiferal $\mathrm{Mg} / \mathrm{Ca}$ ratios, Nature, 405, 442-445, https://doi.org/10.1038/35013033, 2000.

Evans, D., Wade, B. S., Henehan, M., Erez, J., and Müller, W.: Revisiting carbonate chemistry controls on planktic foraminifera $\mathrm{Mg} / \mathrm{Ca}$ : implications for sea surface temperature and hydrology shifts over the Paleocene-Eocene Thermal Maximum and Eocene-Oligocene transition, Clim. Past, 12, 819-835, https://doi.org/10.5194/cp-12-819-2016, 2016.

Fallet, U., Boer, W., Van Assen, C., Greaves, M., and Brummer, G. J. A.: A novel application of wet oxidation to retrieve carbonates from large organic-rich samples for oceanclimate research, Geochem. Geophy. Geosy., 10, Q08004, https://doi.org/10.1029/2009GC002573, 2009.

Fallet, U., Brummer, G. J., Zinke, J., Vogels, S., and Ridderinkhof, H.: Contrasting seasonal fluxes of planktonic foraminifera and impacts on paleothermometry in the Mozambique Channel upstream of the Agulhas Current, Paleoceanography, 25, PA4223, https://doi.org/10.1029/2010PA001942, 2010.

Friedrich, O., Schiebel, R., Wilson, P. A., Weldeab, S., Beer, C. J., Cooper, M. J., and Fiebig, J.: Influence of test size, water depth, and ecology on $\mathrm{Mg} / \mathrm{Ca}, \mathrm{Sr} / \mathrm{Ca}, \delta^{18} \mathrm{O}$ and $\delta^{13} \mathrm{C}$ in nine modern species of planktic foraminifers, Earth Planet. Sc. Lett., 319-320, 133-145, https://doi.org/10.1016/j.epsl.2011.12.002, 2012.

Ganssen, G. and Kroon, D.: Evidence for Red Sea surface circulation from oxygen isotopes of modern surface waters and planktonic foraminiferal tests, Paleoceanography, 6, 73-82, 1991.

Gat, J. R., Shemesh, A., Tziperman, E., Hecht, A., Georgopoulos, D., and Basturk, O.: The stable isotope composition of waters of the eastern Mediterranean Sea, Earth Planet. Sc. Lett., 101, 6441-6451, https://doi.org/10.1016/0012-821X(84)90103$1,1996$.

Geerken, E., de Nooijer, L. J., van Dijk, I., and Reichart, G.J.: Impact of salinity on element incorporation in two benthic foraminiferal species with contrasting magnesium contents, 
Biogeosciences, 15, 2205-2218, https://doi.org/10.5194/bg-152205-2018, 2018.

Gray, W. R., Weldeab, S., Lea, D. W., Rosenthal, Y., Gruber, N., Donner, B., and Fischer, G.: The effects of temperature, salinity, and the carbonate system on $\mathrm{Mg} / \mathrm{Ca}$ in Globigerinoides ruber (white): A global sediment trap calibration, Earth Planet. Sc. Lett., 482, 607-620, https://doi.org/10.1016/j.eps1.2017.11.026, 2018.

Haarmann, T., Hathorne, E. C., Mohtadi, M., Groeneveld, J., Klling, M., and Bickert, $\mathrm{T} .: \mathrm{Mg} / \mathrm{Ca}$ ratios of single planktonic foraminifer shells and the potential to reconstruct the thermal seasonality of the water column, Paleoceanography, 26, 1-14, https://doi.org/10.1029/2010PA002091, 2011.

Hönisch, B., Allen, K. A., Lea, D. W., Spero, H. J., Eggins, S. M., Arbuszewski, J., DeMenocal, P., Rosenthal, Y., Russell, A. D., and Elderfield, H.: The influence of salinity on $\mathrm{Mg} / \mathrm{Ca}$ in planktic foraminifers - Evidence from cultures, core-top sediments and complementary $\delta^{18} \mathrm{O}$, Geochim. Cosmochim. Ac., 121, 196213, https://doi.org/10.1016/j.gca.2013.07.028, 2013.

Huang, K. F., You, C. F., Lin, H. L., and Shieh, Y. T.: In situ calibration of $\mathrm{Mg}$ / Ca ratio in planktonic foraminiferal shell using time series sediment trap: A case study of intense dissolution artifact in the South China Sea, Geochem. Geophy. Geosy., 9, Q04016, https://doi.org/10.1029/2007GC001660, 2008.

Kisakürek, B., Eisenhauer, A., Böhm, F., Garbe-Schönberg, D., and Erez, J.: Controls on shell $\mathrm{Mg} / \mathrm{Ca}$ and $\mathrm{Sr} / \mathrm{Ca}$ in cultured planktonic foraminiferan, Globigerinoides ruber (white), Earth Planet. Sc. Lett., 273, 260-269, https://doi.org/10.1016/j.epsl.2008.06.026, 2008.

Lange, M. and van Sebille, E.: Parcels v0.9: prototyping a Lagrangian ocean analysis framework for the petascale age, Geosci. Model Dev., 10, 4175-4186, https://doi.org/10.5194/gmd-104175-2017, 2017.

Lea, D. W., Mashiotta, T. A., and Spero, H. J.: Controls on magnesium and strontium uptake in planktonic foraminifera determined by live culturing, Geochim. Cosmochim. Ac., 63, 2369-2379, https://doi.org/10.1016/S0016-7037(99)00197-0, 1999.

LeGrande, A. N. and Schmidt, G. A.: Global gridded data set of the oxygen isotopic composition in seawater, Geophys. Res. Lett., 33, 1-5, https://doi.org/10.1029/2006GL026011, 2006.

Mashiotta, T. A., Lea, D. W., and Spero, H. J.: Glacial-interglacial changes in Subantarctic sea surface temperature and $\delta^{18} \mathrm{O}$-water using foraminiferal Mg, Earth Planet. Sc. Lett., 170, 417-432, https://doi.org/10.1016/S0012-821X(99)00116-8, 1999.

Mathien-Blard, E. and Bassinot, F.: Salinity bias on the foraminifera $\mathrm{Mg} / \mathrm{Ca}$ thermometry: Correction procedure and implications for past ocean hydrographic reconstructions, Geochem. Geophy. Geosy., 10, Q12011, https://doi.org/10.1029/2008GC002353, 2009.

McConnell, M. C. and Thunell, R. C.: Calibration of the planktonic foraminiferal $\mathrm{Mg}$ / Ca paleothermometer: Sediment trap results from the Guaymas Basin, Gulf of California, Paleoceanography, 20, 1-18, https://doi.org/10.1029/2004PA001077, 2005.

McConnell, M. C., Thunell, R. C., Lorenzoni, L., Astor, Y., Wright, J. D. and Fairbanks, R.: Seasonal variability in the salinity and oxygen isotopic composition of seawater from the Cariaco Basin, Venezuela: Implications for paleosalinity reconstructions, Geochem. Geophy. Geosy., 10, Q06019, https://doi.org/10.1029/2008GC002035, 2009.
McCrea, J. M. M.: On the isotopic chemistry of carbonates and a paleotemperature scale, J. Chem. Phys., 18, 849-857, https://doi.org/10.1063/1.1747785, 1950.

Mezger, E. M., de Nooijer, L. J., Boer, W., Brummer, G. J. A., and Reichart, G. J.: Salinity controls on Na incorporation in Red Sea planktonic foraminifera, Paleoceanography, 31, 1562-1582, https://doi.org/10.1002/2016PA003052, 2016.

Mezger, E. M., de Nooijer, L. J., Siccha, M., Brummer, G.-J. A., Kucera, M. and Reichart, G. J.: Taphonomic and Ontogenetic Effects on $\mathrm{Na} / \mathrm{Ca}$ and $\mathrm{Mg}$ / Ca in Spinose Planktonic Foraminifera From the Red Sea, Geochem. Geophy., Geosy., 18, 4174-4194, https://doi.org/10.1029/2018GC007852, 2018.

Mezger, E. M., de Nooijer, L. J., Bertlich, J., Bijma, J., Nürnberg, D., and Reichart, G.-J.: Planktonic foraminiferal spine versus shell carbonate $\mathrm{Na}$ incorporation in relation to salinity, Biogeosciences, 16, 1147-1165, https://doi.org/10.5194/bg-161147-2019, 2019.

Mohtadi, M., Steinke, S., Groeneveld, J., Fink, H. G., Rixen, T., Hebbeln, D., Donner, B., and Herunadi, B.: Low-latitude control on seasonal and interannual changes in planktonic foraminiferal flux and shell geochemistry off south Java: A sediment trap study, Paleoceanography, 24, PA1201, https://doi.org/10.1029/2008PA001636, 2009.

Morard, R., Füllberg, A., Brummer, G.-J. A., Greco, M., Jonkers, L., Wizemann, A., Weiner, A. K. M., Darling, K., Siccha, M., Ledevin, R., Kitazato, H., de Gardiel-Thoron, T., de Vargas, C., Kucera, M., De Garidel-Thoron, T., de Vargas, C., Kucera, M., de Gardiel-Thoron, T., de Vargas, C., and Kucera, M.: Genetic and morphological divergence in the warm-water planktonic foraminifera genus Globigerinoides, PLoS One, 14, 1-30, https://doi.org/10.1371/journal.pone.0225246, 2019.

Mulitza, S., Boltovskoy, D., Donner, B., Meggers, H., Paul, A., and Wefer, G.: Temperature: $\delta^{18} \mathrm{O}$ relationships of planktonic foraminifera collected from surface waters, Palaeogeogr. Palaeocl., 202, 143-152, https://doi.org/10.1016/S00310182(03)00633-3, 2003.

Nooteboom, P. D., Bijl, P. K., van Sebille, E., von der Heydt, A. S., and Dijkstra, H. A.: Transport bias by ocean currents in sedimentary microplankton assemblages: Implications for paleoceanographic reconstructions, Paleoceanogr. Paleocl., 34, 1178-1194, https://doi.org/10.1029/2019PA003606, 2019.

Nürnberg, D., Bijma, J., and Hemleben, C.: Assessing the reliability of magnesium in foraminiferal calcite as a proxy for water mass temperatures, Geochim. Cosmochim. Ac., 60, 803-814, https://doi.org/10.1016/0016-7037(95)00446-7, 1996.

Ottens, J. J.: April and August Northeast Atlantic surface water masses reflected in planktic foraminifera, Netherlands J. Sea Res., 28, 261-283, https://doi.org/10.1016/00777579(92)90031-9, 1992.

Pierre, C.: The oxygen and carbon isotope distribution in the Mediterranean water masses, Mar. Geol., 153, 41-55, https://doi.org/10.1016/S0025-3227(98)00090-5, 1999.

Pierre, C., Vergnaud Grazzini, C., Thuoron, D., and Saliège, J.F.: Compositions Isotopiques de L'Oxygène Et Du Carbone Des Masses D'Eau Mèditerranèe, Mem. Soc. Geol. It., 36, 165-174, 1986.

Prahl, F. G. and Wakeham, S. G.: Calibration of unsaturation patterns in long-chain ketone compositions for palaeotemperature assessment, Nature, 330, 367-369, 1987. 
Pujol, C. and Grazzini, C. V.: Distribution patterns of live planktic foraminifers as related to regional hydrography and productive systems of the Mediterranean Sea, Mar. Micropaleontol., 25, 187-217, https://doi.org/10.1016/0377-8398(95)00002-I, 1995.

Rigual-Hernández, A. S., Sierro, F. J., Bárcena, M. A., Flores, J. A., and Heussner, S.: Seasonal and interannual changes of planktic foraminiferal fluxes in the Gulf of Lions (NW Mediterranean) and their implications for paleoceanographic studies: Two 12year sediment trap records, Deep-Sea Res. Pt. I, 66, 26-40, https://doi.org/10.1016/j.dsr.2012.03.011, 2012.

Rohling, E. J.: Progress in paleosalinity: Overview and presentation of a new approach, Paleoceanography, 22, 1-9, https://doi.org/10.1029/2007PA001437, 2007.

Sadekov, A., Eggins, S. M., De Deckker, P., and Kroon, D.: Uncertainties in seawater thermometry deriving from intratest and intertest $\mathrm{Mg} / \mathrm{Ca}$ variability in Globigerinoides ruber, Paleoceanography, 23, 1-12, https://doi.org/10.1029/2007PA001452, 2008.

Schouten, S., Ossebaar, J., Schreiber, K., Kienhuis, M. V. M., Langer, G., Benthien, A., and Bijma, J.: The effect of temperature, salinity and growth rate on the stable hydrogen isotopic composition of long chain alkenones produced by Emiliania huxleyi and Gephyrocapsa oceanica, Biogeosciences, 3, 113-119, https://doi.org/10.5194/bg-3-113-2006, 2006.

Spero, H. J., Eggins, S. M., Russell, A. D., Vetter, L., Kilburn, M. R., and Hönisch, B.: Timing and mechanism for intratest $\mathrm{Mg} / \mathrm{Ca}$ variability in a living planktic foraminifer, Earth Planet. Sc. Lett., 409, 32-42, https://doi.org/10.1016/j.epsl.2014.10.030, 2015.

Stahl, W. and Rinow, U.: Sauerstoffisotopenanalysen an Mittelmeerwässern: Ein Beitrag zur Problematik von Paläotemperaturbestimmungen, "Meteor" Forschungsergebnisse. R. C. Geol. Geophys., 14, 55-59, 1973.

Steinhardt, J., Cléroux, C., Ullgren, J., de Nooijer, L., Durgadoo, J. V., Brummer, G. J., and Reichart, G. J.: Anti-cyclonic eddy imprint on calcite geochemistry of several planktonic foraminiferal species in the Mozambique Channel, Mar. Micropaleontol., 113, 20-33, https://doi.org/10.1016/j.marmicro.2014.09.001, 2014.
Urey, H. C., Lowenstam, H. A., Epstein, S., and McKinney, C. R.: Measurement of Paleotemperatures and Temperatures and the Southeastern United States, B. Geol. Soc. Am., 62, 399-416, https://doi.org/10.1130/00167606(1951)62[399:MOPATO]2.0.CO;2, 1951.

van Dijk, I., de Nooijer, L. J., and Reichart, G.-J.: Trends in element incorporation in hyaline and porcelaneous foraminifera as a function of $p \mathrm{CO}_{2}$, Biogeosciences, 14, 497-510, https://doi.org/10.5194/bg-14-497-2017, 2017.

van Sebille, E., Scussolini, P., Durgadoo, J. V., Peeters, F. J. C., Biastoch, A., Weijer, W., Turney, C., Paris, C. B., and Zahn, R.: Ocean currents generate large footprints in marine palaeoclimate proxies, Nat. Commun., 6, 6521, https://doi.org/10.1038/ncomms7521, 2015.

Vasiliev, I., Reichart, G. J., and Krijgsman, W.: Impact of the Messinian Salinity Crisis on Black Sea hydrology-Insights from hydrogen isotopes analysis on biomarkers, Earth Planet. Sc. Lett., 362, 272-282, https://doi.org/10.1016/j.epsl.2012.11.038, 2013.

Weiss, G. M., Pfannerstill, E. Y., Schouten, S., Sinninghe Damsté, J. S., and van der Meer, M. T. J.: Effects of alkalinity and salinity at low and high light intensity on hydrogen isotope fractionation of long-chain alkenones produced by Emiliania huxleyi, Biogeosciences, 14, 5693-5704, https://doi.org/10.5194/bg-145693-2017, 2017.

Wit, J. C., Reichart, G. J., A Jung, S. J., and Kroon, D.: Approaches to unravel seasonality in sea surface temperatures using paired single-specimen foraminiferal $\delta^{18} \mathrm{O}$ and $\mathrm{Mg} / \mathrm{Ca}$ analyses, Paleoceanography, 25, PA4220, https://doi.org/10.1029/2009PA001857, 2010.

Wit, J. C., de Nooijer, L. J., Wolthers, M., and Reichart, G. J.: A novel salinity proxy based on $\mathrm{Na}$ incorporation into foraminiferal calcite, Biogeosciences, 10, 6375-6387, https://doi.org/10.5194/bg-10-6375-2013, 2013. 